\title{
Chronic Urticaria Due to Allergy to Wheat Alpha-Amylase Inhibitor Proteins
}

\author{
Nagore Arruti Oyarzabal1, Olga Villarreal Balza de Vallejo1, Nagore Bernedo Belar1, \\ Maria Teresa Audicana Berasategui', Natividad Longo Areso', Borja Bartolomé2 \\ ${ }^{1}$ Servicio de Alergia e Inmunología Clínica, Hospital Universitario Araba, Vitoria-Gasteiz, Spain \\ ${ }^{2}$ Bial-Aristegui Laboratories, Bilbao, Spain \\ Email: nagore_arruti@hotmail.com
}

Received 11 March 2016; accepted 18 April 2016; published 21 April 2016

Copyright (C) 2016 by authors and Scientific Research Publishing Inc.

This work is licensed under the Creative Commons Attribution International License (CC BY).

http://creativecommons.org/licenses/by/4.0/

(c) (i) Open Access

\begin{abstract}
Chronic spontaneous urticaria (CSU) is defined as the spontaneous appearance of wheals, angioedema, or both, for at least 6 weeks, due to known or unknown causes [1]. In some patients who present a CSU with daily or almost daily symptoms a type I allergy could be the underlying cause. We present one adult patient with chronic urticaria who was finally diagnosed as a non-occupational case of IgE-mediated wheat allergy manifested following exposure by 3 different routes: inhalation (rhinitis and bronchial asthma), dermal absorption (contact urticaria) and ingestion (systemic chronic urticaria). We were able to detect the culprit proteins by immunoblotting. Serum IgE binds mainly to alpha-amylase/trypsin inhibitors and, to a lesser extent, to other proteins associated with food allergy to grains (e.g. beta-glucanase, serpin, peroxidase). In our opinion, skin prick tests with a food standard battery could help in the etiological diagnosis of chronic urticaria. The identification of responsible allergens could be difficult because only a few complex in vitro techniques allow detecting the allergy to several proteins.
\end{abstract}

\section{Keywords}

Alpha-Amylase Inhibitor, Wheat, Chronic Urticaria, Allergy

\section{Introduction}

Hypersensitivity reactions following cereal intake can be IgE-mediated or not (e.g. celiac disease). There are cases, however, of celiac disease associated with IgE-mediated allergy to cereals [2]. IgE-mediated reactions can occur by inhalation (e.g. Baker's asthma and rhinitis), ingestion (e.g. gastrointestinal manifestations [3], chronic urticaria) and skin absorption (e.g. contact urticaria).

A few prevalence studies of food allergy to cereals have been reported. This sensitization tends to disappear

How to cite this paper: Oyarzabal, N.A., de Vallejo, O.V.B., Belar, N.B., Berasategui, M.T.A., Areso, N.L. and Bartolomé, B. (2016) Chronic Urticaria Due to Allergy to Wheat Alpha-Amylase Inhibitor Proteins. Case Reports in Clinical Medicine, 5, 130-133. http://dx.doi.org/10.4236/crcm.2016.54024 
with age, being rare in adults, in whom could cause the exacerbation of atopic dermatitis [4].

The aim of this paper is to present a case of chronic urticaria which was resolved by avoiding the causative agent, in this case, cereals.

\section{Case Report}

A 29-year-old woman, with no relevant medical or surgical history, had had very pruritic generalized urticaria and occasional angioedema for 1 year. Urticarial lesions appeared daily, especially in the morning when she ate bread at breakfast, and partially improved with antihistamines. Since childhood, she had rhinoconjunctivitis and asthma in places where cereal flour was handled, and contact urticaria when she kneaded bread at home.

The allergy study included skin prick test with a food standard battery, flours and foods containing cereals, measurement of total and specific IgE (CAP, Thermofisher ${ }^{\circledR}$; ISAC microarray), and SDS-PAGE immunoblotting (in reducing and non-reducing conditions of electrophoresis). Positive results were obtained with flour mixture, gliadin, wheat, barley, rye and corn, whereas prick by prick with oat and different foods containing cereals (e.g. Coca-Cola ${ }^{\circledR}$, cacao drink, soluble cereals) [5] were negative. Total IgE was $331 \mathrm{kUA} / \mathrm{l}$. Specific IgE results were positive with barley $(61.8 \mathrm{kUA} / \mathrm{l})$, rye $(50.3 \mathrm{kUA} / \mathrm{l})$, wheat $(6.99 \mathrm{kUA} / \mathrm{l})$ and gluten $(3.48 \mathrm{kUA} / \mathrm{l})$, and negative $(<0.35 \mathrm{kUA} / \mathrm{l})$ with rice, corn, $\omega 5$-gliadin and rPru p3. Tri a 14 (LTP), Tri a 19 ( $\omega 5$-gliadin), nTria aATI (trypsin inhibitor) and buckwheat (2S albumin) analysed with the ISAC microarray system were also negative.

SDS-PAGE immunoblotting performed with wheat, barley, rye, oat, rice, corn and gluten, showed low molecular weight IgE binding bands (around $14 \mathrm{kDa}$ ). As shown in Figure 1 (immunoblot with electrophoresis done under non-reducing conditions), the bands in the samples of wheat, barley, rye, oat, and gluten, may represent $\alpha$-amylase/trypsin inhibitor family proteins.

Negative anti-tissue transglutaminase autoantibodies and normal immunoglobulin count were detected in blood analysis.

The patient tolerated oral food challenge with rice and corn, being diagnosed of contact and chronic urticaria, and rhinitis and bronchial asthma due to allergy to wheat $\alpha$-amylase inhibitor. The symptoms had been resolved without receiving any treatment, after avoiding the ingestion of cereals (wheat, barley, rye and oat) for 15 days. We allowed rice and corn intake due to the good tolerance demonstrated in the controlled oral challenge.

\section{Discussion}

Gramineae family members are distributed in different subfamilies. The Pooidae subfamily includes Triticeae (wheat, rye, barley) and Aveneae (oat) tribes. Certain cross-reactivity has been described between members of the Triticeae tribe [6], but there are different patterns of clinical tolerance.

\section{SDS-PA GE Immunoblotting}

(Without 2-mercaptoethanol)

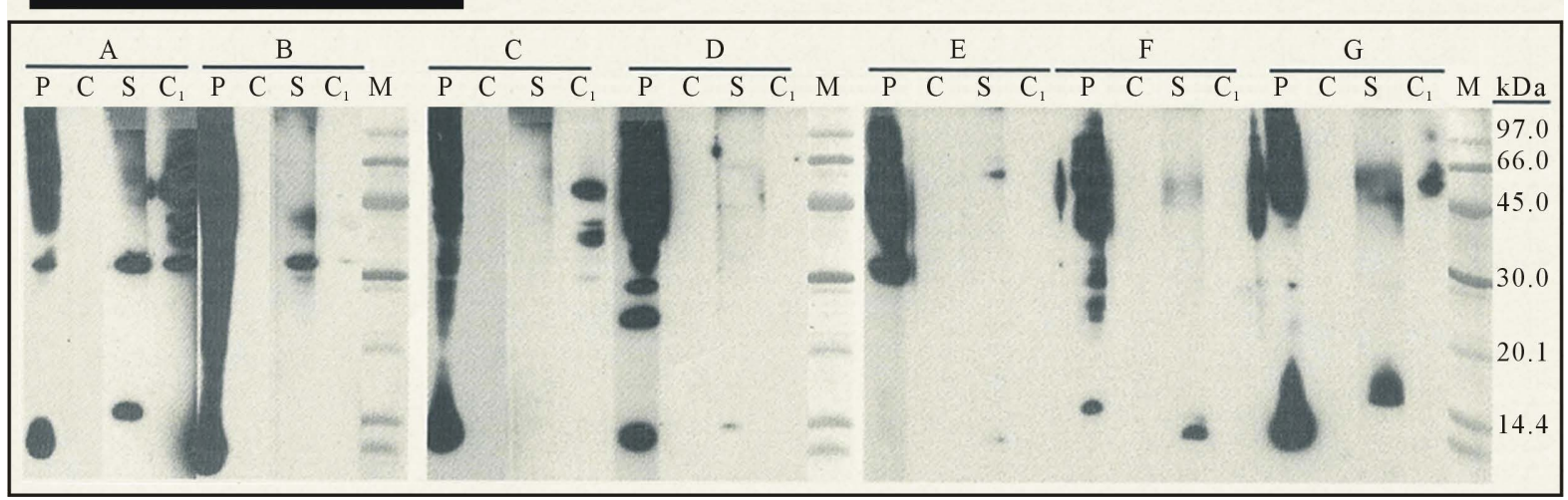

Proven extracts: A) Wheat seed; B) Barley seed; C) Rye seed; D) Oat seed; E) Round rice; F) Dry corn; G) Gluten

Sera used: P) Peatient's serum; C) Control serum (pooled sera from non-atopic individuals); S) Anti-LTP serum; C1) Rabbit serum (negative control); M) Molecular weight markers

Figure 1. Immunoblot with electrophoresis performed under non-reducing conditions with seeds (wheat, barley, rye and oats) and extracts (rice, corn and gluten). 
The cereal grain proteins may act as allergens in cereal flour and according to their solubility in different solvents can be grouped into different protein fractions: albumin, globulin and gluten proteins (prolamins and glutenins) [7]. These proteins have different biological functions, such as storage, metabolic, structural and defense [8].

Most salt-soluble proteins are enzymes and enzyme inhibitors, whereas the salt-insoluble (e.g. gluten proteins) are usually seed storage proteins and constitute $80 \%$ of the protein fraction of cereal grain. Many of these proteins (gluten, enzymes, enzyme inhibitors, surface proteins) act as the major allergens in Baker's asthma and food allergy to cereals (e.g. $\alpha$-amylase/trypsin inhibitors, LTP, serpin).

Within the prevalence studies of food allergy to cereals, there is an observational study carried out in Spain (Alergológica 2005), in which cereals represented only 3.3\% of all food allergens [9]. There are few reports of chronic urticaria due to wheat intake. Kanny et al. described an adult with chronic urticaria and asthma due to allergy to wheat flour (based on specific IgE to wheat flour and positive oral challenge test) [10]. Mingomataj et al. diagnosed allergy to alpha-gliadin by a positive prick test in another adult who showed chronic urticaria, headache, arthralgia and amenorrhea. Their symptoms resolved after a gluten-free diet [11].

Our patient was sensitized to wheat alpha-amylase inhibitors, which have a defensive role against digestive alpha-amylases of different parasites. They come from the grain endosperm and are present in all wheat protein fractions (albumins, globulins, gliadins, glutenins) [12]. They are salt soluble proteins and their molecular mass is around 12 - $16 \mathrm{kDa}$. There are 11 allergenic proteins belonging to this family that may cause allergy by inhalation and/or ingestion (those being major allergens in Baker's asthma and wheat food allergy in children and adults) [7] [13]. The reactions by ingestion are often associated with exercise or atopic dermatitis.

As the main route of sensitization to flour is inhalatory, our patient could be sensitized in childhood and adolescence manipulating raw flour daily for making homemade bread, manifesting asthma and rhinitis, and later developing a food allergy in the form of urticaria that can be regarded as chronic (given that it lasted for longer than 6 weeks).

\section{Conclusions}

We consider this case of interest as our patient is an adult with IgE-mediated allergy to wheat manifested following exposure by 3 different routes: inhalation (rhinitis and bronchial asthma), dermal absorption (contact urticaria) and ingestion (systemic chronic urticaria). We were able to detect the culprit proteins by immunoblotting. Serum IgE binds mainly to $\alpha$-amylase/trypsin inhibitors and, to a lesser extent, to other proteins related to food allergy by grains (e.g. beta-glucanase, serpin, peroxidase).

The study of patients with chronic urticaria should include screening for a food allergy because it may be helpful in rare instances as in our case. The actual prevalence of the sensitization to the $\alpha$-amylase/trypsin inhibitor proteins in cereal allergy is unknown in part because there are only a few complex in vitro techniques that allow its detection.

\section{Acknowledgements}

No external funding was received for the present study.

\section{Competing Interests}

The authors declare that they have no conflicts of interest. ISAC microarray and SDS-PAGE immunoblotting techniques were carried out with the help from Dr. Borja Bartolomé, director of the applications laboratory of the pharmaceutical company Bial-Aristegui.

\section{Authors' Contributions}

All authors have been involved in drafting the manuscript and revising it critically, giving final approval of the version to be published.

\section{References}

[1] Zuberbier, T., Aberer, W., Asero, R., Bindslev-Jensen, C., Brzoza, Z., Canonica, G.W., et al. (2014) The EAACI/GA² 
LEN/EDF/WAO Guideline for the Definition, Classification, Diagnosis, and Management of Urticaria: The 2013 Revision and Update. Allergy, 69, 868-887. http://dx.doi.org/10.1111/all.12313

[2] Pastorello, E.A., Aversano, M.G., Mascheri, A., Farioli, L., Losappio, L.M., Mirone, C., et al. (2015) Celiac Disease in a Patient with Baker's Asthma and Wheat Allergy Due to Tri a 14. Case Reports in Clinical Medicine, 4, 253-256. http://dx.doi.org/10.4236/crcm.2015.47050

[3] Simonato, B., De Lazzari, F., Pasini, G., Polato, F., Giannattasio, M., Gemignani, C., et al. (2001) IgE Binding to Soluble and Insoluble Wheat Flour Proteins in Atopic and Non-Atopic Patients Suffering from Gastrointestinal Symptoms after Wheat Ingestion. Clinical \& Experimental Allergy, 31, 1771-1778. http://dx.doi.org/10.1046/j.1365-2222.2001.01200.x

[4] Czaja-Bulsa, G. and Bulsa, M. (2014) The Natural History of IgE Mediated Wheat Allergy in Children with Dominant Gastrointestinal Symptoms. Allergy, Asthma \& Clinical Immunology, 10, 12. http://dx.doi.org/10.1186/1710-1492-10-12

[5] Armentia-Medina, A., Martín-Gil, F.J., Arranz-Peña, M.L., Bañuelos-Ramón, M.C., Navas-Heredia, M.C., Pardo, M. (1998) Food Allergy to Coca-Cola ${ }^{\circledR}$ and Cola Cao ${ }^{\circledR}$ and Its Relation with Purified Cereal Proteins. Alergia alimentaria a Coca-Cola ${ }^{\circledR}$ y Cola Cao ${ }^{\circledR}$ y su relación con proteínas purificadas de cereales. Revista Española de Alergología e Inmunología Clínica, Diciembre, 13, 339-346.

[6] Palosuo, K., Alenius, H., Varjonen, E., Kalkkinen, N. and Reunala, T. (2001) Rye $\gamma$-70 and $\gamma$-35 Secalins and Barley $\gamma$-3 Hordein Cross-React with $\omega$-5 Gliadin, a Major Allergen in Wheat-Dependent, Exercise-Induced Anaphylaxis. Clinical \& Experimental Allergy, 31, 466-473. http://dx.doi.org/10.1046/j.1365-2222.2001.01023.x

[7] Tatham, A.S. and Shewry, P.R. (2008) Allergens in Wheat and Related Cereals. Clinical \& Experimental Allergy, 38, 1712-1726.

[8] Shewry, P.R. and Halford, N.G. (2002) Cereal Seed Storage Proteins: Structures, Properties and Role in Grain Utilization. Journal of Experimental Botany, 53, 947-958. http://dx.doi.org/10.1093/jexbot/53.370.947

[9] Fernández-Rivas, M. (2009) Food Allergy in Alergológica-2005. JIACI, 19, 37-44.

[10] Kanny, G., Chenuel, B. and Moneret-Vautrin, D.A. (2001) Chronic Urticaria to Wheat. Allergy, 56, 356-357. http://dx.doi.org/10.1034/j.1398-9995.2001.00050.x

[11] Mingomataj, E.C., Gjata, E., Bakiri, A., Xhixha, F., Hyso, E. and Ibranji, A. (2011) Gliadin Allergy Manifested with Chronic Urticaria, Headache and Amenorrhea. BMJ Case Reports, 2011. http://dx.doi.org/10.1136/bcr.10.2011.4907

[12] Pastorello, E.A., Farioli, L., Conti, A., Pravettoni, V., Bonomi, S., et al. (2007) Wheat IgE-Mediated Food Allergy in European Patients: $\alpha$-Amylase Inhibitors, Lipid Transfer Proteins and Low Molecular Weight Glutenins. International Archives of Allergy and Immunology, 144, 10-22. http://dx.doi.org/10.1159/000102609

[13] Salcedo, G., Quirce, S. and Diaz-Perales, A. (2011) Wheat Allergens Associated with Baker's Asthma. JIACI, 21, 8192. 